\title{
A COMPREHENSIVE REVIEW OFTHE LOCAL RISK-FACTORS ASSOCIATED WITH THE ETIOLOGY OF PERI-IMPLANT DISEASES
}

\author{
Mohammed Alshehri ${ }^{1 a^{*}}$ \\ 'Dental Department, King Khalid University Hospital, King Saud University, Riyadh, Saudi Arabia \\ aBDS, AEGD, SSC-ARD, SF-DI, Consultant in Cosmetic, Restorative and Implant Dentistry
}

Cite this article:

Alshehri M. A comprehensive review of the local risk-factors associated with the etiology of peri-implant diseases. Stoma Edu J. 2016;3(3-4):193-199.

Background: A variety of factors (local and systemic) have been associated with the etiology of periimplant diseases.

Objective: The aim was to provide an overview of current literature regarding the local risk-factors associated with the etiology of peri-implant diseases.

Data sources: Indexed databases were searched till June 2016 using different combinations of the following key words: "bruxism"; "oral biofilm"; "peri-implant diseases"; "peri-implantitis", "riskfactors" and "smoking".

Study selection: Clinical studies assessing the local risk-factors associated with the etiology of periimplantitis were included. Letters to the Editor, case-reports, case-series, in-vitro studies, studies on animal models and commentaries were excluded.

Data extraction: The pattern of the present comprehensive review was customized to primarily summarize the pertinent information.

Data synthesis: Poor bone density and volume are associated with the etiology of peri-implant diseases. Excessive plaque accumulation and history of periodontitis are core etiological factors associated with peri-implant diseases. The relative risk for peri-implantitis was significantly higher in patients with a previous history of periodontitis compared to peri-implantitis patients without a history of periodontal disease. Periodontopathogens associated with periodontitis have also been isolated from peri-implant sulci of patients with peri-implantitis. Peri-implantitis is most often manifested in patients with bruxism and tobacco smoking habit. Other factors associated with the etiology of peri-implant diseases include presence of cement excess and operator's clinical experience. Bone quality and quantity, poor oral hygiene, smoking, bruxism, occlusal overloading, history of periodontitis and operator's experience are common local factors associated peri-implant diseases.

Keywords: dental implant, osseointegration, bruxism, smoking, periodontitis.

\section{Introduction}

Dental implants are an innovative replacement for traditional fixed and removable dental prosthesis such as bridges and dentures, respectively ${ }^{1}$. Numerous studies ${ }^{2-4}$ have reported implant success and survival rates of up to $100 \%$. Nevertheless, with the increasing number of patients receiving dental implants, the prevalence of peri-implant diseases has also increased ${ }^{1,5}$. Peri-implant diseases are categorized into two types namely, peri-implant mucositis and periimplantitis. Peri-implant mucositis is characterized by soft tissue inflammation around the implant without any signs of alveolar bone loss $^{6}$. The clinical signs of peri-implant mucositis include bleeding on probing (BOP) and/or suppuration, which are usually associated with probing depth (PD) of at least 4 millimeters ( $\mathrm{mm}$ ) with no evidence of radiographic loss of bone ${ }^{7,8}$. According to a consensus report from the 6th European Workshop on Periodontology, peri-implantitis is defined as the presence of inflammation of the peri-implant mucosa and concurrent loss of supporting alveolar bone ${ }^{6}$. Mombelli et al. ${ }^{9}$ described peri-implantitis as a site-specific inflammatory condition, which displays clinical and radiographic features that

\section{*Corresponding author:}

Dr. Mohammad Alshehri, DDS, PhD, Assistant Professor and Consultant, Dental Department, King Khalid University Hospital, King Saud University Riyadh, Saudi Arabia

Tel: +96655380333, Fax: +966114672428,e-mail:dr_mzs@hotmail.com 
are similar to those in patients with chronic periodontitis. Data regarding the prevalence of peri-implantitis are inconsistent. In the study by Koldsland et al. ${ }^{10}$, the prevalence of peri-implantitis ranged between $11.3 \%$ and $47.1 \%$; whereas Mombelli et al. ${ }^{11}$ reported peri-implantitis in $20 \%$ of their study population during 5 to 10 years of follow-up. In the study by Zitzmann and Berglundh ${ }^{6}$, the frequency of peri-implantitis varied between $28 \%$ and at least $56 \%$ of the participants and $12 \%$ and $43 \%$ of individual implants.

A variety of factors (local and systemic) have been associated with the etiology of peri-implantitis ${ }^{12-16}$. The most common local factor that has been reported to trigger an inflammatory response around dental implants is the oral biofilm. Moreover, tissues around implants are also more susceptible to oral biofilm-associated infections that spread into the alveolar bone and may cause bone loss ${ }^{17}$. Furthermore, a variety of destructive inflammatory cytokines have been identified in the peri-implant crevicular fluid of patients with periimplantitis ${ }^{18}$. These cytokines have been reported to aggravate peri-implant inflammation and bone loss $^{18}$. Although biologic differences exist between natural teeth and implants, Belibasakis ${ }^{19}$ suggested that peri-implantitis corresponds to periodontitis. Other local factors that have been associated with the etiology of peri-implantitis include quality and quantity of recipient bone, jaw location, tobacco smoking, history of periodontitis, bruxism, habitual alcohol consumption, implant surface topography and implant overloading. Nevertheless, the contribution of systemic factors such as immunosuppression (as observed in patients with acquired immune deficiency syndrome, osteoporosis, poorly-controlled diabetes mellitus and cancer) and the use of medications (such as bisphosphonates and corticosteroids) that have also been associated with the etiology of periimplantitis cannot be disregarded ${ }^{20-24}$.

Considering the length of the review, the author reserved the present review to comprehensively review the local risk-factors associated with the etiology of peri-implantitis. With this background, the aim of the present comprehensive review was to provide an overview of current literature regarding the local risk-factors associated with the etiology of peri-implantitis.

\section{Material and methods \\ 2.1. Focused question}

The focused question addressed was "What are the local risk-factors associated with the etiology of peri-implant diseases?"

\subsection{Literature search strategy}

PubMed/Medline, Scopus, EMBASE, ISI Web of knowledge and Google-Scholar databases were searched till June 2016 using the following key words: "bruxism"; "oral biofilm"; "peri-implant diseases"; "peri-implantitis", "risk-factors" and "smoking". Clinical studies assessing the local riskfactors associated with the etiology of peri-implant diseases were included (Fig. 1).

\subsection{Eligibility criteria}

Results from only clinical studies were included. Letters to the Editor, historic reviews, case-reports, case-series, in-vitro studies, studies on animal models and commentaries were excluded. The pattern of the present comprehensive review was customized to primarily summarize the pertinent information (Fig. 1).

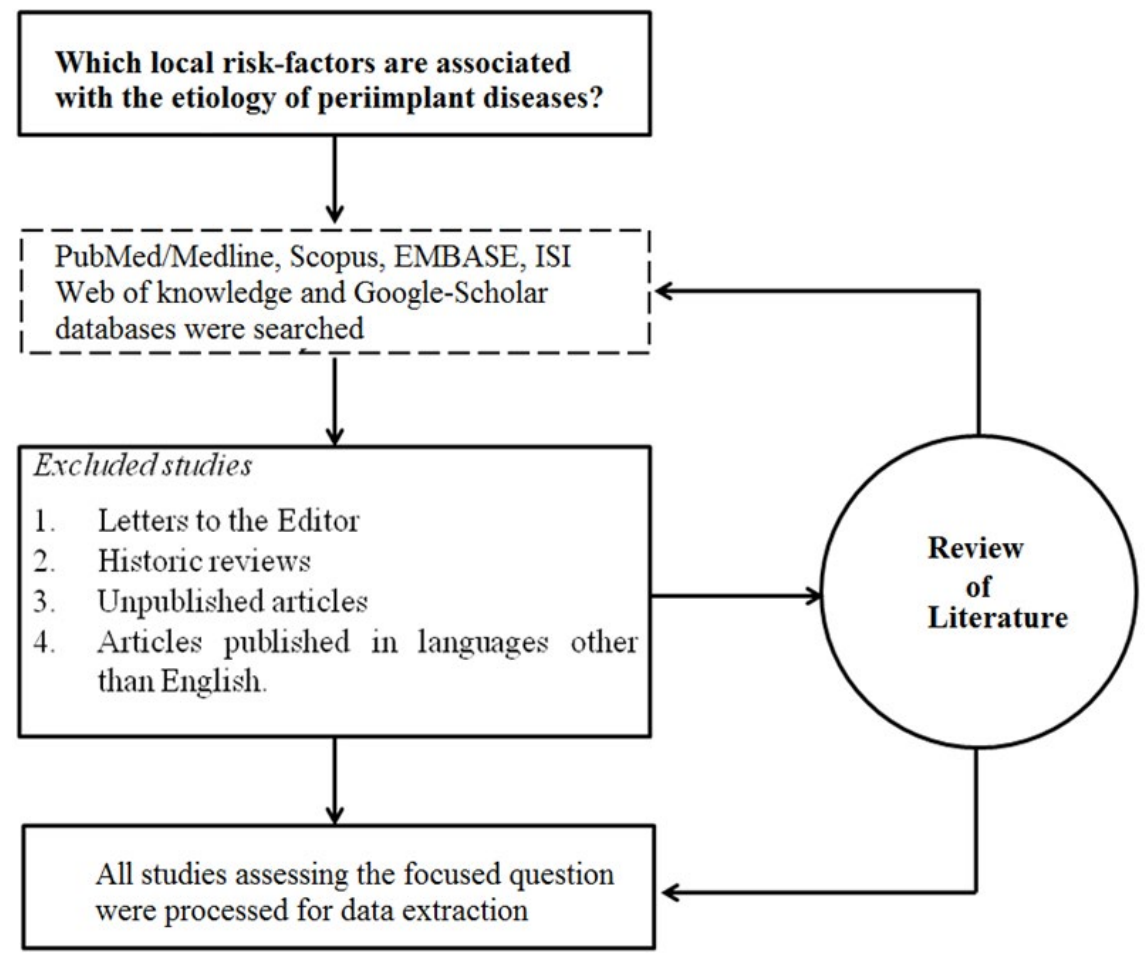

Figure 1. Literature search strategy 


\section{Results}

Local risk-factors associated with the etiology of peri-implant diseases are summarized in Fig. 2.

\subsection{Bone quality}

Studies have reported that peri-implant bone loss is more often manifested in the maxilla, which is composed of less dense bone as compared to the mandible. It has also been suggested that compromised bone density is the most critical factor associated with peri-implant bone loss ${ }^{25}$; whereas others suggest that both poor bone density and volume are associated with the etiology of peri-implant diseases and bone $\operatorname{loss}^{26-27}$.

\subsection{Poor oral hygiene}

Studies from human biopsies ${ }^{28,29}$ have shown that peri-implantitis and periodontitis lesions have several features in common. One of such features is poor oral hygiene maintenance. The dental plaque is the core etiological factor that causes the development of oral biofilm around the teeth and dental implant surfaces ${ }^{30-34}$. In the study by Serino and Ström ${ }^{35}$, most of the implants with a diagnosis of peri-implantitis were associated with no accessibility and/or capability for appropriate oral hygiene measures. This study ${ }^{35}$ concluded that oral hygiene at the implant sites is most likely associated with the presence or absence of peri-implantitis. Moreover, studies ${ }^{36-42}$ have also reported that microbes residing in the oral biofilm such as Aggregatibacter actinomycetemcomitans, Enterococcus fecalis, Porphyromonas gingivalis, and Staphylococcus aureus (which are also associated with the etiology of periodontitis) play a role in the initiation of peri-implantitis. It is therefore predictable to find a significant relationship between peri-implant bone loss and poor oral hygiene. In this regard, it is imperative for oral healthcare providers to educate patients regarding the significance of regular oral hygiene maintenance and routine dental checkups towards the establishment of peri-implant and periodontal maintenance.

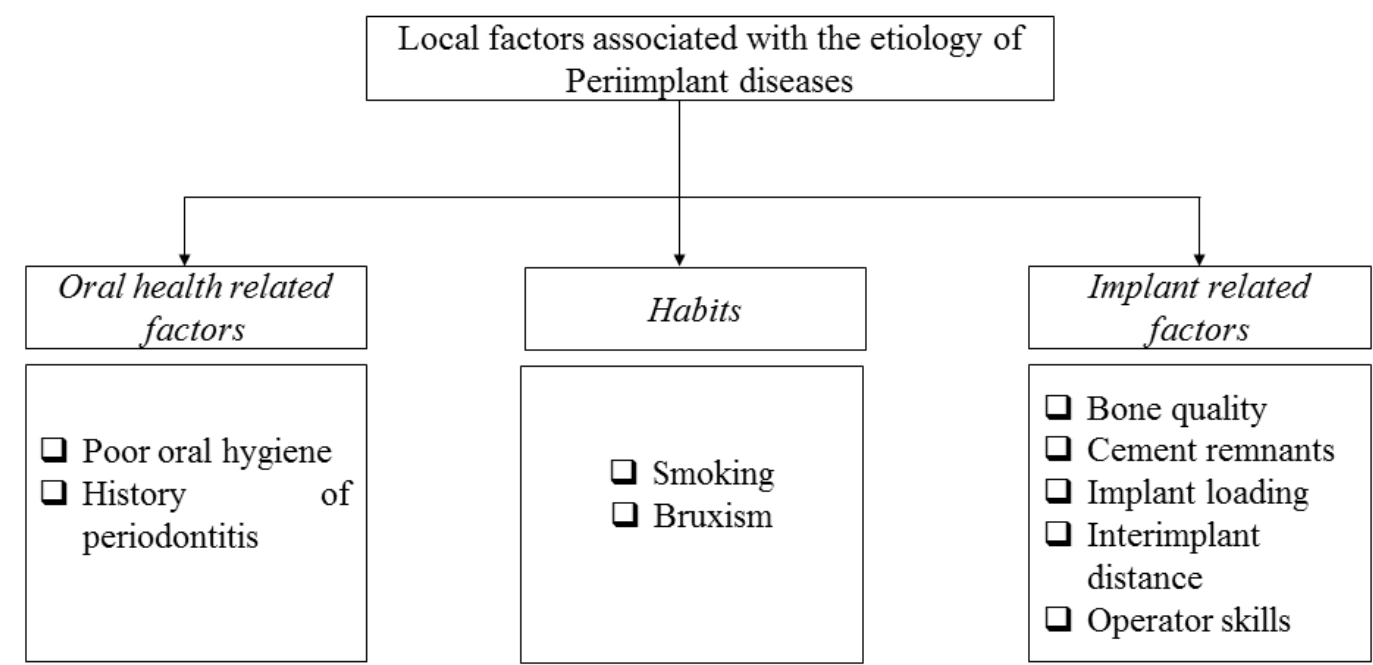

Figure 1. A diagrammatic presentation of the local risk factors associated with the etiology of peri-implant diseases

\subsection{History of periodontitis}

It has been claimed that peri-implantitis is a common finding in patients with a history of periodontitis ${ }^{43-44}$. Results from a systematic review and meta-analysis showed that the relative risk for peri-implantitis was significantly higher in patients with a previous history of periodontitis compared to peri-implantitis patients without a history of periodontal disease ${ }^{43}$. However, in a recent study, Meyle et al. ${ }^{45}$ investigated the longterm clinical and radiographic parameters of osseointegrated implants in non-smoking patients with a previous history of chronic periodontitis. The results showed that patients with a previous history of periodontitis regularly attending an oral hygiene maintenance program displayed implant survival rates up to $100 \%$ after 5 and 10 years. Similarly, in a systematic review, Pesce et al. ${ }^{46}$ concluded that there is a lack of consensus regarding the role of periodontitis in the etiology of peri-implantitis. Nevertheless, since several periodontopathogens (such as Aggregatibacter actinomycetemcomitans, Prevotella intermedia and Porphyromonas gingivalis) associated with the etiology of periodontitis have also been isolated from peri-implant sulci of patients with periimplantitis ${ }^{47-50}$. In a recent study, Jorand et al. ${ }^{30}$ reported that Desulfovibrio fairfieldensis is one of the most relevant sulphate-reducing bacteria of the human oral cavity suspected to be involved in peri-implantitis and implant corrosion. It is arduous to disregard the hypothesis that peri-implantitis is more common in patients with a history of periodontitis.

\subsection{Smoking}

It is well-established that periodontal inflammation and marginal bone loss are more often manifested in tobacco smokers as compared to individuals not using tobacco in any form ${ }^{51-54}$. Studies ${ }^{12,55-57}$ have also reported that cigarette smokers are more susceptible to develop peri-implantitis as 
compared to non-smokers. In a systematic review and metaanalysis, Sgolastra et al. ${ }^{57}$ assessed the role of smoking as a risk factor for peri-implantitis. The implant-based meta-analysis showed a significantly higher risk of peri-implantitis in smokers [Relative risk: 2.1, 95\% Confidence interval: 1.34-3.29, $p=0.001$ ) than non-smokers. The mechanism behind peri-implant bone loss in smokers is most probably similar to periodontal bone loss. Tsigarida et al. ${ }^{12}$ proposed that that smoking shapes the peri-implant microbiomes even in states of clinical health, by supporting a pathogen-rich community. Although the mechanisms by which smoking enhances alveolar bone loss are poorly understood; evidence suggests that smoking enhances bone loss by affecting the host response. Smoking has been reported to impair the function of neutrophils that cause decreased chemotaxis, phagocytosis, and adherence 58,59 . Moreover, it has also been reported that smokers present a decreased oxygen tension in periodontal pockets that could favor anaerobic microbial colonization ${ }^{60,61}$. The same mechanism could be associated with peri-implant diseases, such as peri-implant mucositis and peri-implantitis. It has also been suggested that there is a synergistic effect of tobacco smoking and carriage of interleukin-1 gene polymorphism that results in increased risk of peri-implantitis ${ }^{62,63}$. Moreover, tobacco smoking has also been reported to jeopardize the outcomes of periodontal surgical interventions ${ }^{64}$. Galindo-Moreno et al. ${ }^{65}$ reported that the rates of marginal bone loss around implants are significantly associated with smoking. Results from a recent systematic review and metaanalysis also reported a significantly higher risk of peri-implantitis in smokers as compared to nonsmokers ${ }^{66}$.

\subsection{Bruxism}

There are only a limited number of case-reports that have associated the occurrence of peri-implantitis with bruxism. In a case-report, Merin RL ${ }^{67}$ described the case of a 63-year-old female patient with a history of bruxism who reported to the clinic with pain and discomfort around an implant placed in the tooth no. 30 position. Radiographic evaluation showed that this implant had significant periimplant bone loss. The author observed that the peri-implant bone loss was associated with heavy occlusion on the implant restoration ${ }^{67}$. The author performed an occlusal adjustment and a radiograph taken five months after occlusal adjustment showed significant repair of the lost alveolar bone ${ }^{67}$. Similar results were reported in another case-report by Lin et al. ${ }^{68}$

\subsection{Cement remnants}

A conventional approach towards restoration of dental implant using fixed prosthesis is the use of cement-retained restorations. In the absence of occlusal screw access openings, cementretained restorations are useful in enhancing the number of occlusal contacts and simultaneously improving aesthetics ${ }^{69}$. However, inadequate removal of excessive cement at the time of implant cementation may lead to a complication, cement-induced peri-implantitis ${ }^{69}$. The probability of cement to remain in the peri-implant sulcus is high when margins of the restoration are placed $1.5 \mathrm{~mm}$ to $3 \mathrm{~mm}$ subgingivally ${ }^{70}$. In a recent systematic review, Pesce et al. ${ }^{71}$ appraised the currently available scientific evidence to assess the role played by cement excess and misfitting components on the development of peri-implantitis. The authors reported that there is a correlation between cement excess and the presence of peri-implant disease, particularly among patients with a history of periodontitis ${ }^{71}$. The authors also emphasized that removal of excess cement by means of debridement helps resolve most of the symptoms of peri-implantitis ${ }^{71}$. Similarly, in a retrospective clinical observational study of fixed implant-supported restorations, cement associated peri-implantitis was assessed ${ }^{72}$. In this study, 71 patients with 126 implants were investigated. Cement residues were identified in $59.5 \%$ of the implants. BOP was observed in $80 \%$ of the implants and suppuration at $21.3 \%$ of the implants with excess cement. The results demonstrated that following removal of the excess cement and recementation, a $76.9 \%$ reduction in BOP occurred with no signs of suppuration at follow-up. However, according to Korsch and Walther ${ }^{73}$, the frequency of undetected excess cement depends upon the type of cement used. Premier Implant Cement (PIC) tends to leave more undetected excess as compared to Temp Bond (TB) cement. In this regard, implants cemented with PIC tend to have a higher prevalence for periimplant inflammation and cause a more severe peri-implant bone loss as compared to those cemented with $\mathrm{TB}^{73}$.

\subsection{Occlusal overloading}

Occlusal overloading is a major cause of biomechanical implant complications including fracture and/or loosening of the implant. Occlusal overloading (combined with plaque accumulation) may also disturb the intricate bond between the implant surface and bone thereby leading to periimplantitis and, if left untreated, implant failure ${ }^{74-76}$. Prevention of occlusal overloading is associated with performing comprehensive examinations, treatment planning, well-defined surgical and prosthetic treatments and regular maintenance. However, conflicting results have also been reported 77,78 . In a study on dogs, there was no loss of osseointegration and/or peri-implantitis following a period of 8 months of excessive occlusal load on titanium implants ${ }^{78}$.

\subsection{Interimplant distance}

Studies have reported that the horizontal distance between two adjacent implants can also influence $\mathrm{CBH}^{79-81}$. It has been reported that when two implants are placed adjacent to one another, the distance between them influences the degree of lateral bone loss and interproximal bone peak resorption ${ }^{81}$. This phenomenon is 
independent of the time of implant loading and surface characteristics ${ }^{82}$. In a histomorphometric study, Elian et al. ${ }^{83}$ compared the effects of two interimplant distances ( $2 \mathrm{~mm}$ and $3 \mathrm{~mm}$ ) on bone maintenance with bone level implants. The results showed that the interproximal bone loss measured from the edge of the implant platform to the bone crest was not different for interimplant distances of $2 \mathrm{~mm}$ or $3 \mathrm{~mm}$. Moreover, according to Tarnow et al. ${ }^{81}$, an interimplant distance of greater than 3 millimeters $(\mathrm{mm})$ between two adjacent implants helps preserve the interproximal bone peak and results in an average bone resorption of 0.45 $\mathrm{mm}$ up to 3 years of follow up. However, under circumstances where the distance between the implants is less than or equal to $3 \mathrm{~mm}$, the average resorption of the interproximal bone peak increases to $1.04 \mathrm{~mm}$, which in turn compromises support for the interimplant papilla ${ }^{81}$. Results by Tarnow et al. ${ }^{81}$ also demonstrated that when the distance from the base of the contact point to the crest of bone was $3 \mathrm{~mm}, 4 \mathrm{~mm}$ or $5 \mathrm{~mm}$, the papilla was present almost $100 \%$ of the time; however, when the distance was $7 \mathrm{~mm}, 8 \mathrm{~mm}, 9 \mathrm{~mm}$, or 10 $\mathrm{mm}$, the papilla was mostly missing. To the author's knowledge from indexed literature, the influence of interimplant distance on crestal bone loss around dental implants remains unclear.

\subsection{Surgical skills and experience of operator}

Surgical trauma and/or limited clinical experience

\section{REFERENCES}

1. Romanos GE, Javed F, Delgado-Ruiz RA, Calvo-Guirado JL. Periimplant diseases: a review of treatment interventions. Dent Clin North Am. 2015;59(1):157-178.

2. Lombardo G, Pardo A, Mascellaro A, Corrocher G, Marincola M, Costantinescu FE, Nocini PF. Rehabilitation of severely resorbed maxillae with zygomatic implants: a literature review. Stoma Edu J. 2015;2(1):69-78.

3. Fenner N, Hammerle CH, Sailer I, Jung RE. Long-term clinical, technical, and esthetic outcomes of all-ceramic vs. titanium abutments on implant supporting single-tooth reconstructions after at least 5 years. Clin Oral Implants Res. 2016;27(6):716-723.

4. Jeong MA, Jung MK, Kim SG, Oh JS. Implant Stability Measurements in the Long-Term Follow-up of Dentis Implants: A Retrospective Study With Periotest. Implant Dent. 2015;24(3):263-266.

5. Tonetti MS. Risk factors for osseodisintegration. Periodontology 2000. 1998; 17:55-62.

6. Zitzmann NU, Berglundh T. Definition and prevalence of peri-implant diseases. J Clin Periodontol. 2008;35(8 Suppl):286-291.

7. Khammissa RA, Feller L, Meyerov R, Lemmer J. Peri-implant mucositis and peri-implantitis: clinical and histopathological characteristics and treatment. SADJ 2012;67(3):122,4-6.

8. Jankovic S, Aleksic Z, Dimitrijevic B, Lekovic V, Camargo P, Kenney B. Prevalence of human cytomegalovirus and Epstein-Barr virus in subgingival plaque at peri-implantitis, mucositis and healthy sites. A pilot study. Int J Oral Maxillofac Surg. 2011;40(3):271-276.

9. Mombelli A, van Oosten MA, Schurch E, Jr., Land NP. The microbiota associated with successful or failing osseointegrated titanium implants. Oral Microbiol Immunol. 1987;2(4):145-151.

10. Koldsland OC, Scheie AA, Aass AM. Prevalence of peri-implantitis related to severity of the disease with different degrees of bone loss. $J$ Periodontol. 2010;81(2):231-8.

11. Mombelli A, Muller N, Cionca N. The epidemiology of peri-implantitis. Clin Oral Implants Res. 2012;23 Suppl 6:67-76.

12. Tsigarida AA, Dabdoub SM, Nagaraja HN, Kumar PS. The Influence of Smoking on the Peri-Implant Microbiome. J Dent Res. 2015;94(9):1202-1217.

13. Ferreira SD, Silva GL, Cortelli JR, Costa JE, Costa FO. Prevalence and risk variables for peri-implant disease in Brazilian subjects. J Clin Periodontol. 2006;33(12):929-935.

14. Degidi M, Nardi D, Piattelli A. 10-year prospective cohort follow- have been considered as one of the most essential factors associated with the etiology of peri-implant diseases ${ }^{84,85}$. It has been reported that peri-implant disease are more often manifested among authors who have placed less than 50 dental implants as compared to those who have placed more than 50 implants ${ }^{86,87}$. Moreover, overheating of bone during implant placement procedures may result in osteonecrosis thereby inviting peri-implant diseases and even implant failure ${ }^{88}$.

\section{Recommendations}

It is highly recommended that oral healthcare providers practicing implant dentistry should be aware of the risk factors associated with periimpalnt diseases. Adequate knowledge of such risk-factors may also be useful in selecting patients for future implant therapy. Simultaneously, it is imperative for healthcare providers to educate their patients (including those who have either received dental implants or those that are potential candidates for future dental implant therapy) about the detrimental effects of these risk-factors on the long-term success and survival of dental implants.

\section{Conflict of interest and financial disclosure}

The author reports no conflict of interest and there was no external source of funding for the present study.

up of immediately restored XiVE implants. Clin Oral Implants Res. 2016;27(6):694-700

15. Miyata T, Kobayashi Y, Araki H, Ohto T, Shin K. The influence of controlled occlusal overload on peri-implant tissue. Part 3: A histologic study in monkeys. Int J Oral Maxillofac Implants. 2000;15(3):425-431. 16. Wahlstrom M, Sagulin GB, Jansson LE. Clinical follow-up of unilateral, fixed dental prosthesis on maxillary implants. Clin Oral Implants Res. 2010;21(11):1294-300.

17. Lindhe J, Berglundh T, Ericsson I, Liljenberg B, Marinello C. Experimental breakdown of peri-implant and periodontal tissues. A study in the beagle dog. Clin Oral Implants Res. 1992;3(1):9-16.

18. Javed F, Al-Hezaimi K, Salameh Z, Almas K, Romanos GE. Proinflammatory cytokines in the crevicular fluid of patients with peri-implantitis. Cytokine. 2011;53(1):8-12.

19. Belibasakis GN. Microbiological and immuno-pathological aspects of peri-implant diseases. Arch Oral Biol. 2014;59(1):66-72.

20. Vohra F, Al-Rifaiy MQ, Almas K, Javed F. Efficacy of systemic bisphosphonate delivery on osseointegration of implants under osteoporotic conditions: lessons from animal studies. Arch Oral Biol. 2014;59(9):912-920.

21. Javed F, Almas K. Osseointegration of dental implants in patients undergoing bisphosphonate treatment: a literature review. J Periodontol. 2010;81(4):479-484.

22. Javed F, Romanos GE. Impact of diabetes mellitus and glycemic control on the osseointegration of dental implants: a systematic literature review. J Periodontol. 2009;80(11):1719-1730.

23. Javed F, Al-Hezaimi K, Al-Rasheed A, Almas K, Romanos GE. Implant survival rate after oral cancer therapy: a review. Oral Oncol. 2010;46(12):854-859.

24. Lu SY, Huang CC. Resolution of an active peri-implantitis in a chronic steroid user by bone augmentation with PepGen P-15 and a barrier membrane. J Oral Implantol. 2007;33(5):280-287.

25. Duyck J, Naert I. Failure of oral implants: aetiology, symptoms and influencing factors. Clin Oral Investig. 1998;2(3):102-114.

26. Hutton JE, Heath MR, Chai JY, Harnett J, Jemt T, Johns RB, et al. Factors related to success and failure rates at 3-year follow-up in a multicenter study of overdentures supported by Branemark implants. Int J Oral Maxillofac Implants. 1995;10(1):33-42.

27. Jemt T, Chai J, Harnett J, Heath MR, Hutton JE, Johns RB, et al. A 5-year prospective multicenter follow-up report on overdentures supported by 
osseointegrated implants. Int J Oral Maxillofac Implants. 1996;11(3):291

298.

28. Zitzmann NU, Berglundh T, Marinello CP, Lindhe J. Expression of endothelial adhesion molecules in the alveolar ridge mucosa, gingiva and peri-implant mucosa. J Clin Periodontol. 2002;29(6):490-495.

29. Konttinen YT, Lappalainen R, Laine P, Kitti U, Santavirta S, Teronen O. Immunohistochemical evaluation of inflammatory mediators in failing implants. Int J Periodontics Restorative Dent. 2006;26(2):135-141.

30. Jorand FP, Debuy S, Kamagate SF, Engels-Deutsch M. Evaluation of a biofilm formation by Desulfovibrio fairfieldensis on titanium implants. Letters Appl Microbiol. 2015;60(3):279-287.

31. Javed F, Al Amri MD, Al-Kheraif AA, Qadri T, Ahmed A, Ghanem A, et al. Efficacy of non-surgical periodontal therapy with adjunct Nd:YAG laser therapy in the treatment of periodontal inflammation among patients with and without type 2 diabetes mellitus: A short-term pilot study. J Photochem Photobiol B. 2015;149:230-234.

32. Alshehri FA, Javed F. Impact of scaling and root planing on clinical periodontal status and glycemic levels in prediabetic patients. Interv Med Appl Sci. 2015;7(1):17-21

33. Javed F, Al-Kheraif AA, Al Amri MD, Mikami T, Vohra F, Warnakulasuriya $\mathrm{S}$, et al. Periodontal parameters and whole salivary cytokine profiles among habitual gutka chewers and non-chewers. J Periodontol. 2015:86(5):689-695.

34. Javed F, Ahmed HB, Mehmood A, Mikami T, Malmstrom H, Romanos GE. Self-perceived oral health and periodontal parameters in chronic periodontitis patients with and without rheumatoid arthritis. J Investig Clin Dent. 2016;7(1):53-58.

35. Serino G, Strom C. Peri-implantitis in partially edentulous patients: association with inadequate plaque control. Clin Oral Implants Res. 2009;20(2):169-174.

36. Heitz-Mayfield LJ, Lang NP. Comparative biology of chronic and aggressive periodontitis vs. peri-implantitis. Periodontol 2000. 2010;53:167 181.

37. Leonhardt A, Renvert S, Dahlen G. Microbial findings at failing implants. Clin Oral Implants Res. 1999;10(5):339-345.

38. Colombo AV, Barbosa GM, Higashi D, di Micheli G, Rodrigues PH Simionato MR. Quantitative detection of Staphylococcus aureus, Enterococcus faecalis and Pseudomonas aeruginosa in human oral epithelia cells from subjects with periodontitis and periodontal health. J Med Microbiol. 2013;62(Pt 10):1592-600.

39. Canullo L, Rossetti PH, Penarrocha D. Identification of Enterococcus Faecalis and Pseudomonas Aeruginosa on and in Implants in Individuals with Peri-implant Disease: A Cross-Sectional Study. Int J Oral Maxillofac Implants. 2015;30(3):583-587.

40. Shibli JA, Melo L, Ferrari DS, Figueiredo LC, Faveri M, Feres M. Composition of supra- and subgingival biofilm of subjects with healthy and diseased implants. Clin Oral Implants Res. 2008;19(10):975-982.

41. Grenier D, Chen H, Ben Lagha A, Fournier-Larente J, Morin MP. Dual Action of Myricetin on Porphyromonas gingivalis and the Inflammatory Response of Host Cells: A Promising Therapeutic Molecule for Periodontal Diseases. PloS one. 2015;10(6):e0131758.

42. Zhuang LF, Watt RM, Mattheos N, Si MS, Lai HC, Lang NP. Periodontal and peri-implant microbiota in patients with healthy and inflamed periodontal and peri-implant tissues. Clin Oral Implants Res. 2016;27(1):13 21.

43. Sgolastra F, Petrucci A, Severino M, Gatto R, Monaco A. Periodontitis, implant loss and peri-implantitis. A meta-analysis. Clin Oral Implants Res. 2015;26(4):e8-16

44. Swierkot K, Lottholz P, Flores-de-Jacoby L, Mengel R. Mucositis, periimplantitis, implant success, and survival of implants in patients with treated generalized aggressive periodontitis: 3- to 16-year results of a prospective long-term cohort study. J Periodontol. 2012;83(10):1213-1225. 45. Meyle J, Gersok G, Boedeker RH, Gonzales JR. Long term analysis of osseointegrated implants in non-smoker patients with a previous history of periodontitis. J Clin Periodontol. 2014;41(5):504-512.

46. Pesce P, Menini M, Tealdo T, Bevilacqua M, Pera F, Pera P. Peri-implantitis: a systematic review of recently published papers. Int J Prosthodont. 2014;27(1):15-25

47. Vargas-Reus MA, Memarzadeh K, Huang J, Ren GG, Allaker RP Antimicrobial activity of nanoparticulate metal oxides against periimplantitis pathogens. Int J Antimicrobial Agents. 2012;40(2):135-139 48. Tamura N, Ochi M, Miyakawa H, Nakazawa F. Analysis of bacterial flora associated with peri-implantitis using obligate anaerobic culture technique and 16S rDNA gene sequence. Int J Oral Maxillofac Implants. 2013:28(6):1521-1529.

49. Irshad M, Scheres N, Crielaard W, Loos BG, Wismeijer D, Laine ML. Influence of titanium on in vitro fibroblast-Porphyromonas gingivalis interaction in peri-implantitis. J Clin Periodontol. 2013;40(9):841-849. 50. Liu P, Liu Y, Wang J, Guo Y, Zhang Y, Xiao S. Detection of Fusobacterium Nucleatum and fadA Adhesin Gene in Patients with Orthodontic
Gingivitis and Non-Orthodontic Periodontal Inflammation. PloS one. 2014;9(1):e85280.

51. Javed F, Nasstrom K, Benchimol D, Altamash M, Klinge B, Eng strom PE. Comparison of periodontal and socioeconomic status between subjects with type 2 diabetes mellitus and non-diabetic controls. J Periodontol. 2007; 78(11):2112-2119.

52. Javed F, Al-Askar M, Samaranayake LP, Al-Hezaimi K. Periodontal disease in habitual cigarette smokers and nonsmokers with and without prediabetes. Am J Med Sci. 2013;345(2):94-98.

53. Javed F, Al-Kheraif AA, Al Amri MD, Alshehri M, Vohra F, Al-Askar $M$, et al. Periodontal Status and Whole Salivary Cytokine Profile Among Smokers and Never-Smokers With and Without Prediabetes. J Periodontol. 2015;86(7):890-8.

54. Javed F, Al-Kheraif AA, Salazar-Lazo K, Yanez-Fontenla V, Aldosary $\mathrm{KM}$, Alshehri $\mathrm{M}$, et al. Periodontal Inflammatory Conditions Among Smokers and Never-Smokers With and Without Type 2 Diabetes Mellitus. J Periodontol. 2015;86(7):839-46.

55. Saaby M, Karring E, Schou S, Isidor F. Factors influencing severity of peri-implantitis. Clin Oral Implants Res. 2016;27(1):7-12.

56. de Waal YC, Raghoebar GM, Meijer HJ, Winkel EG, van Winkelhoff AJ. Prognostic indicators for surgical peri-implantitis treatment. Clin Oral Implants Res. 2016;27(12):1485-1491

57. Sgolastra F, Petrucci A, Severino M, Gatto R, Monaco A. Smoking and the risk of peri-implantitis. A systematic review and meta-analysis. Clin Oral Implants Res. 2015;26(4):e62-7.

58. Kraal JH, Kenney EB. The response of polymorphonuclear leukocytes to chemotactic stimulation for smokers and non-smokers. J Periodontal Res. 1979;14(5):383-389.

59. Kenney EB, Kraal JH, Saxe SR, Jones J. The effect of cigarette smoke on human oral polymorphonuclear leukocytes. J Periodontal Res. 1977;12(4):227-234

60. Hanioka T, Tanaka M, Takaya K, Matsumori Y, Shizukuishi S. Pocket oxygen tension in smokers and non-smokers with periodontal disease. J Periodontol. 2000;71(4):550-554

61. van Winkelhoff AJ, Bosch-Tijhof CJ, Winkel EG, van der Reijden WA. Smoking affects the subgingival microflora in periodontitis. J Periodontol. 2001:72(5):666-671.

62. Laine ML, Leonhardt A, Roos-Jansaker AM, Pena AS, van Winkelhoff AJ, Winkel EG, et al. IL-1RN gene polymorphism is associated with peri-implantitis. Clin Oral Implants Res. 2006;17(4):380-385

63. Gruica B, Wang HY, Lang NP, Buser D. Impact of IL-1 genotype and smoking status on the prognosis of osseointegrated implants. Clin Oral Implants Res. 2004;15(4):393-400.

64. Javed F, Al-Rasheed A, Almas K, Romanos GE, Al-Hezaimi K. Effect of cigarette smoking on the clinical outcomes of periodontal surgical procedures. Am J Med Sci. 2012;343(1):78-84.

65. Galindo-Moreno P, Leon-Cano A, Ortega-Oller I, Monje A, F OV Catena A. Marginal bone loss as success criterion in implant dentistry: beyond $2 \mathrm{~mm}$. Clin Oral Implants Res. 2014

66. Sgolastra F, Petrucci A, Severino M, Gatto R, Monaco A. Smoking and the risk of peri-implantitis. A systematic review and meta-analysis. Clin Oral Implants Res. 2015;26(4):e62-67.

67. Merin RL. Repair of peri-implant bone loss after occlusal adjustment: a case report. J Am Dent Assoc. (1939). 2014;145(10):10581062.

68. Lin WS, Ercoli C, Lowenguth R, Yerke LM, Morton D. Oral rehabilitation of a patient with bruxism and cluster implant failures in the edentulous maxilla: a clinical report. J Prosthet Dent. 2012;108(1):1-8.

69. Pette GA, Ganeles J, Norkin FJ. Radiographic appearance of commonly used cements in implant dentistry. Int J Periodontics Restorative Dent. 2013:33(1):61-68.

70. Linkevicius T, Vindasiute E, Puisys A, Peciuliene V. The influence of margin location on the amount of undetected cement excess after delivery of cement-retained implant restorations. Clin Oral Implants Res. 2011;22(12):1379-1384.

71. Pesce P, Canullo L, Grusovin MG, de Bruyn H, Cosyn J, Pera P. Systematic review of some prosthetic risk factors for peri-implantitis. $J$ Prosthetic Dent. 2015;114(3):346-350

72. Korsch M, Obst U, Walther W. Cement-associated peri-implantitis: a retrospective clinical observational study of fixed implant-supported restorations using a methacrylate cement. Clin Oral Implants Res. 2014:25(7):797-802.

73. Korsch M, Walther W. Peri-Implantitis Associated with Type of Cement: A Retrospective Analysis of Different Types of Cement and Their Clinical Correlation to the Peri-Implant Tissue. Clin Implant Dent Relat Res. 2015;17 Suppl 2:e434-443.

74. Naert I, Duyck J, Vandamme K. Occlusal overload and bone/implant loss. Clin Oral Implants Res. 2012;23 Suppl 6:95-107.

75. Klinge B, Meyle J. Peri-implant tissue destruction. The Third EAO Consensus Conference 2012. Clin Oral Implants Res. 2012;23 Suppl 6:108-110. 
76. Chambrone L, Chambrone LA, Lima LA. Effects of occlusal overload on peri-implant tissue health: a systematic review of animal-model studies. J Periodontol. 2010;81(10):1367-1378.

77. Chang M, Chronopoulos V, Mattheos N. Impact of excessive occlusal load on successfully-osseointegrated dental implants: a literature review. J Investig Clin Dent. 2013;4(3):142-150.

78. Heitz-Mayfield LJ, Schmid B, Weigel C, Gerber S, Bosshardt DD, Jonsson J, et al. Does excessive occlusal load affect osseointegration? An experimental study in the dog. Clin Oral Implants Res. 2004;15(3):259-268.

79. Elian N, Jalbout ZN, Cho SC, Froum S, Tarnow DP. Realities and limitations in the management of the interdental papilla between implants: three case reports. Pract Proced Aesthet Dent. 2003;15(10):737744; quiz 46.

80. Elian N, Bloom M, Dard M, Cho SC, Trushkowsky RD, Tarnow D. Effect of interimplant distance ( 2 and $3 \mathrm{~mm}$ ) on the height of interimplant bone crest: a histomorphometric evaluation. J Periodontol. 2011:82(12):1749-1756.

81. Tarnow DP, Cho SC, Wallace SS. The effect of inter-implant distance on the height of inter-implant bone crest. J Periodontol. 2000;71(4):546-549

82. Hermann JS, Buser D, Schenk RK, Cochran DL. Crestal bone changes around titanium implants. A histometric evaluation of unloaded non-submerged and submerged implants in the canine mandible. J Periodontol. 2000;71(9):1412-1424.

83. Elian N, Bloom M, Trushkowsky RD, Dard MM, Tarnow D. Effect of 3 and 4-mm interimplant distances on the height of interimplant bone crest: a histomorphometric evaluation measured on bone level dental implants in minipig. Implant Dent. 2014;23(5):522-528.

84. el Askary AS, Meffert RM, Griffin T. Why do dental implants fail? Part I. Implant Dent. 1999;8(2):173-185.

85. el Askary AS, Meffert RM, Griffin T. Why do dental implants fail? Part II. Implant Dent. 1999;8(3):265-277.

86. Morris HF, Manz MC, Tarolli JH. Success of multiple endosseous dental implant designs to second-stage surgery across study sites. J Oral Maxillofac Surg. 1997;55(12 Suppl 5):76-82.

87. Friberg B, Jemt T, Lekholm U. Early failures in 4,641 consecutively placed Branemark dental implants: a study from stage 1 surgery to the connection of completed prostheses. Int J Oral Maxillofac Implants. 1991:6(2):142-146

88. Eriksson RA, Albrektsson T. The effect of heat on bone regeneration: an experimental study in the rabbit using the bone growth chamber. J Oral Maxillofac Surg. 1984;42(11):705-711.

\section{Mohammad ALSHEHRI \\ DS, AEGD, SSC-ARD, SF-DI, Consultant in Cosmetic Restorative and Implant Dentistry Dental Department, College of Medicine King Saud University Riyadh, Saudi Arabia}

Dr Alshehri graduated from the College of Dentistry, King Saud University in 2001. Academically, he has acquired a Certificate in Advanced Education in General Dentistry at the University of Southern California, School of Dentistry. Thereafter, Dr Alshehri joined the SBARD Program wherein he obtained the Saudi Specialty Certificate in Advanced Restorative Dentistry. Subsequently, he was able to obtain a Certificate for Saudi Fellowship in Dental Implant and is currently a Fellow of International Team for Implantology (ITI).

Professionally, Dr Alshehri has conducted multiple research projects, has obtained a number of patents and has made local and international presentations. Currently, Dr Alshehri is a Consultant in Cosmetic, restorative and implant dentistry at College of Medicine and University Hospitals and board member of the Saudi Dental Society.

\section{Orestions}

\section{Peri-implant mucositis is characterized by}

$\square$ a. Necrotizing gingiva;

ab. Bone loss;

口. Soft tissue inflammation;

$\square d$. None of the above.

\section{Peri-implantitis corresponds to periodontitis. However, it does not cause bone loss:}

口a. Both statements are true;

b. Both statements are false;

$\square$ c. The first statement is false but the second statement is true;

$\square \mathrm{d}$. The first statement is true but the second statement is false.

\section{The risk factors of peri-implantitis include:}

口a. Smoking;

ab. Poor oral hygiene;

ac. Bruxism;

$\square d$. All of the above.

\section{Occlusal overloading of the implant may be prevented by}

口a. Using short implants;

ab. Using cement retained implants;

ac. Comprehensive examination and treatment planning;

$\square d$. Using wide diameter implants. 